\title{
200 号記念特集
}

21 世紀への社会学的想像力一一新しい共同性と公共性

\section{特集〈21 世紀への社会学的想像力 新しい共同性と公共性}

$\begin{array}{lll}\text { 西原 和 } & \text { 久 } \\ \text { 渡辺 秀 } & \text { 樹 }\end{array}$

本号は, 『社会学評論』 200 号記念として「21世紀への社会学的想像力一一新し い共同性と公共性」を特集する「日本社会の非近代性」という特集を組んだ第 1 号の創刊は 1950 年であり，50年後のこの 200 号はちょうど世紀の転換占に位置す る.そして，この時占が新たな現代的課題とも取り組まなけれげならない時期で あることは誰の眼にも明らかであろう。特集を組むにあたって執筆者にお願いし たことは，21世紀に向けて，「私化 (privatization)」や「個人主義化」をこえた新 しい共同性や公共性のあり方，新しい「公共哲学」をどのように考えていくのか， この占をめくる各論者の社会学的展望を示す論稿の執筆であった

ここで, 特集タイトルにある「社会学的想像力」や「共同性」や「公共性」と いう語を定義つけるつもりはない たたし，共同性が，F テンニースなとの名前 を出すまでもなく，19世紀以来社会学の基本テーマであり続けているし，また日 本社会学も, 農村や都市・地域研究なとのなかでこの論題に関して大きな成果と 蓄積をもっているその先行研究は踏まえられる必要があるだろう。

しかし, 輚後 50 年も過ぎ, 日本は“豊かな社会”になった。創刊号か「非近代 性」を問題にし, 近代化へ向けた思索をはしめたのに対し，50年後の現在は，近 代批判といった形で「近代（モタン）」の問い直しの思索を経験している その当 否は別として，ポストモタン状况にあるとされるなかで，「近代」という地平での 「私」の問題や, 現代社会の豊かさのなかでの「私化」の問題などが，人間観の変 容，家族や地域社会の変容などともからめられながら論しられてきた

しかも，時代は「国民国家」の枠をこえて，「グローハリセーションの時代」だ と語られている。もちろん, 経斉面だけでなく, 情報や文化の面, あるいは環境 問題などでもクローハルな視野が必要になってきたことは間違いないくわえて, 
「社会主義の崩壊」後のグローバルな資本主義社会化も着目されなければならない だろう。ローカルな場をこえる広い局域・グローバルな視点が必要となってきた. それゆえ,この局面では, 「公」のあり方があらためて自覚化されてきたといって よい. 古い共同性と新しい公共性, あるいは「公」と「私」の対立問題などの議 論が, 自覚的に語られてきた.

しかし，事態はもち万んそれほど単純な図式ではない，共同性と公共性，公と 私，あるいはミクロ／局域とマクロ／広域などの問題は，たとえば既成の枠をこ えるNGO・NPOの運動や「想像の共同体」といった議論などを考えてみても分 かるように，それらの間の相互浸透や相互関係の一層の複雑化を伴っている. ま た，障害学やフェミニズムの視点なども旧来の思考の枠組みの再検討を迫ってい る.だからじつは, こうした公・私, 共・公, ミクロ・マクロなどといった単純 な二分法それ自体の有効性も問われはじめているといった方がよいかもしれない.

こうした点を, 単に理念的なレベルの議論だけではなく, 各領域での実証研究 にも裏打ちされた蓄積をふまえた上で再検討する必要がある。もち万ん，いまま での内外の社会学的知見を参照しながらの再検討は, 必然的に「理論化」という 作業も伴う. その意味で, 理論社会学的. 社会哲学的な先行研究の検討も不可欠 であることはいうまでもない.「理論と実証」という古くからの言葉をかみしめな がら, 想像力の翼を広げて, 新しい時代の共同性と公共性のあり方を, 本特集は 考えていくことになる.

な押, 本特集への執筆の依頼は, 社会学評論編集委員会内のワーキンググルー プ（長谷川公一・橋爪大三郎・西原和久 ・渡辺秀樹）の立案に基づいて委員会決 定した. 国外研究や所属機関の事情などの理由で執筆を辞退・断念された方もあ つたが, 現在, 日本社会学会の世代的にも中堅で活躍している方々に執筆願った. 研究領域のバランス, 実証研究や理論研究の交流などを視野に入れた人選を行っ たつもりであるが, 多くの会員のなかから限られた人数の方にのみ執筆願わざる をえなかった，ただし，若手の会員の方には，本誌204号で「21世紀の社会学へ 一一視点と構想」という，本特集と関連した論文公募の企画があるので，この場 を借りて多数の応募を期待していると述べて抢きたい. 本特集と次の特集を契機 に，過去となりつつある 20 世紀を踏まえながら，世紀の転換点である現在の研究 成果の上で, 未来の 21 世紀を展望する社会学研究がさらに活性化することを願っ ている. 最後に, 本号は, 福岡安則委員の尽力で『社会学評論スタイルガイド』 に完全準拠する作業を行ったことを付け加えておきたい.今後の 200 号以降の 『社会学評論』が, 大いに社会学研究の成果の提示と議論の場となることを願う次 第である.

(名古屋大学教授) (慶應義塾大学教授) 